\title{
Dangerous Beauty-Thoughts on Paradise Lost
}

\author{
Yongli Liu',a \\ ${ }^{1}$ Science and Technology College of Hubei University for Nationalities, Enshi, Hubei, 445000 \\ a1159288650@qq.com
}

Key Words: Dangerous beauty, Milton, Paradise Lost, Male writers

\begin{abstract}
From the ancient time on, women have been regarded as evils. The stereotyped thought “dangerous beauty” has been deeply rooted in people's mind. By analyzing Paradise Lost, this essay pounders upon Milton's idea of “dangerous woman” and tries to point out that many male writers hold this idea.
\end{abstract}

\section{Introduction}

Cihai defines "dangerous woman" as: woman who causes disasters to the man related to her. Stemmed from the ancient time, this idea has been widely spread all over the world. Since the disasters were often considered relating to beautiful women, who were so beautiful that man would despise his family, his city or even his country for want of her. Women were taken as criminals, and their bad names were told to the later generation. In ancient China, those goody-goody Taoist were quite prejudiced against beautiful women. The reason was that they were so frightened of women that they considered women the evils. It's quite clear that men tended to blame women whatever mistakes they committed.

\section{“Dangerous Beauty” in Paradise Lost}

Lived in male-dominated society, the world-renown British poet Milton is also quite prejudiced against women. Readers can feel it in his works. Milton lived in $17^{\text {th }}$ century of British society, and his life was filled with legend as well as disasters. He was highly esteemed by people all over the world. He had written a lot of political pamphlets such as: A Speech for the Liberty of Unlicensed Printing to the Parliament of England; Iconoclast, Areopagitica to encourage the British people to promote freedom. But in wedlock, Milton suffered a lot. In 1642, he took Mary as his wife. But in less than two months they separated because of different political ideas, and Mary lived in her mother's house for more than 3 years. Two days after giving birth to the fourth child, Mary died in 1652. His second wife Catherine died of childbirth after two years' marriage. The marriage with Elizabethan finally brought him peace while at this time Milton had lost the ability to take care of himself for he was totally blind. The misfortunes in marriage pushed him to think of The Principles and Rule of Divorce, which was quite radical in his time. It was under this continuous sufferings that he left the world heritage Paradise Lost, Paradise Regained and Samson Agonistes.

Paradise Lost , a masterpiece of the world literature and thoughts, reveals man's original sin and degradation. It expresses Milton's strong desire of pursuing freedom, and it also shows great originality and superiority of the writer. Bittered by the disasters and misfortunes in his marriages, Milton seems to blame Eve in his representative work Paradise Lost. In the epic, he laboriously depicts the process of how human beings violated God's will and were expelled out of Garden of Eden. At the very beginning, God created the human ancestor Adam, and then created Eve out of 
Adam's rib. They lived happily in the Garden of Eden made by the Creator. One day when they went out to work as usual, Eve wanted to do her part separately to improve work efficiency.

"Adam, well may we labour still to dress

This garden, still to tend plant, herb and flow'r,

Our pleasant task enjoined, but till more hands

Aid us, the work under our labour grows,

Luxurious by restraint; what we by day

Lop overgrown, or prune, or prop, or bind,

One night or two with wanton growth derides

Tending to wild. Thou therefore now advise

Or hear what to my mind first thoughts present;

Let us divide our labours, thou where choice

Leads thee, or where most needs, whether to wind

The woodbine round this arbour, or direct

The clasping ivy where to climb, while I

In yonder spring of roses intermixed

With myrtle, find what to redress till noon: "[1]

To whom mild answer Adam thus returned.

Sole Eve, associate sole, to me beyond

Compare above all living creatures dear,

God hath assigned us, nor of me shalt pass

Unpraised: for nothing lovelier can be found

In woman, than to study household good,

And good works in her husband to promote.

Or this, or worse, leave not the faithful side

That gave thee being, still shades thee and protects.

The wife, where danger or dishonour lurks,

Safest and seemliness by her husband stays,

Who guards her, or with her the worst endures.

But Eve consoled him of not being tempted or seduced, and Adam replied:

Daughter of God and man, immoral Eve,

For such thou art, from sin and blame entire:

Not different of thee do I dissuade

Thy absence from my sight, but to avoid......

With many words to warn Eve not to be tempted by evil power, and his reasoning of God's good will, in the end, Adam gave in.

Go; for thy stay, not free, absents thee more;

Go in thy native innocence, rely

On what thou hast of virtue, summon all, [2]

Thus Eve happily separated with Adam. The mere serpent in appearance had waited this chance for so long a time. "Beyond his hope, Eve separate he spies." Remembering all the tortures in the Hell, Satan determined to tempt Eve to eat the "fruit of fairest colours mixed, Ruddy and gold." Driven by curiosity, hunger and thirst, Eve followed the serpent to "the tree of prohibition, root of all our woe.” Forth reaching to the fruit, she plucked, she ate. Greedily she engorged without restraint, And knew not eating death. After the eating, 
Scarce from the tree returning; in her hand

A bough of fairest fruit that downy smiled, ......

On th' other side, Adam, soon as he heard

The fatal trespass done by Eve, amazed,

Astonished stood and blank, while horror chill

Ran through his veins, and all his joints relaxed;

from his slack hand the garland wreathed for Eve

Down dropped, and all the faded roses shed:

Speechless he stood and pale.[3]

All out of love for Eve, Adam became brave enough to taste the fruit with his wife.

Earth trembled from her entrails, as again

In pangs, and Nature gave a second groan;

Sky loured, and muttering thunder, some sad drops

Wept at completing of mortal sin

Original; while Adam took no thought,

Eating his fill..... [4]

Thus human beings had been totally degenerated by their behaviors. God was so furious that he dispelled them out of Garden of Eden; and to the woman thus his sentence turned.

Thy sorrow I will greatly multiply

By thy conception, children thou shalt bring

In sorrow forth, and to thy husband's will

Thine shall submit, he over thee shall rule.

On Adam last thus judgment he pronounced.

Because thou hast hearkened to the voice of thy wife,

And eaten of the tree concerning which

I charged thee, saying: Thou shalt not eat thereof,

Cursed is the ground for thy sake, thou in sorrow

Shalt eat thereof all the days of thy life;

Thorns also and thistles it shall bring thee forth

Unbid, and thou shalt eat the herb of the field,

In the sweat of thy face shalt thou eat bread,

Till thou return unto the ground, for thou

Out of the ground was taken; know thy birth,

For dust thou art, and shalt to dust return. [5]

This process of human fall was vividly presented to the readers. According to the ideas expressed by Milton, it was all because of Eve that human beings suffered loss. She persisted to separate to work, and this provides the golden chance for Satan. Without the company of her husband, Eve was easily tempted by evil power, thus she fell first. But Adam's love to his wife quickened the fall of the whole human beings. He finally agreed to taste the forbidden fruit with his wife together, leading to the complete degeneration of mankind. Readers can find that in the logic, it was women who caused the fall of men, it was women who caused the loss of human beings. Thus "dangerous beauty" is prominent in Milton's work. Because of the ancestors fall, the seeds of theirs had to suffer generation by generation. But it is unfair to say so. If Adam was so determined not to let Eve go to work alone, he could have stopped all the things happened. And Even "God declaring that the entrance of Satan could not be by them prevented.” For long before Satan came to the Garden of Eden, God had foreseen the fall of man kind. But why let the gentle woman shoulder the 
responsibility?

In another epic Samson Agonistes, Milton put Delilah to blame. Samson Agonistes was a superman with extraordinary power and no one can destroy him. In order to defeat him, the enemy sought to Delilah to seduce him to tell his secret. Finally Samson Agonistes was captured and his hair was cut, for he told Delilah his secret lied in his hair. With his hair cut, Samson Agonistes was an ordinary man without superpower, he was easily destroyed by his enemy. [6] For the ruin of Samson, many people criticized Delilah's betrayal and faithless. It seems that it was the "dangerous woman" who caused the disaster. But people with brain can think themselves. Had Samson Agonistes the man had his own principle in front of women, can Delilah do anything to him? In a sense, Samson Agonistes was destroyed by himself, not the others. If he was not so proud of himself, if he didn't indulge himself in women, he would have another story. How can this woman be called "dangerous woman”?

The Chinese writer Lu Xun once said "I never believed in the saying that Zhao Jun's marriage to Xiong $\mathrm{Nu}$ (ferocious tribe of ancient China) can bring peace to Han dynasty, Mu Lan's recruitment to the army can make Sui dynasty live longer; nor do I believed in the saying that it is Da Ji -concubine of emperor Yin destroyed Yin dynasty. To me, women couldn't have the mighty power in male-dominated society. It is men's responsibility to shoulder the prosperity or decline of a nation. But strangely, male writers tend to blame women in history. ” [7]

But what Mr. Lu Xun despised has never come to an end. Too many a time women were criticized for being the disasters of men and their nation. In his famous tragedy Macbeth, Shakespeare also expressed the idea of “dangerous beauty”. In the play, Shakespeare wrote that Macbeth was leaded by his wife to kill the king, and it was his wife who helped him kill the king. It was true that Lady Macbeth was ambitious enough, and she was bold enough to encourage her husband to do something big. But if Macbeth was a loyal subject, who harbors no evil ambitions, Lady Macbeth can only be blamed for her unwanted desires. [8] Since Macbeth had the evil desires, under the temptation of his wife, he was so easy to take action. If people were to blame Lady Macbeth, they must believe that women were so powerful that their words influence a lot. If so, the whole human society wouldn't have so many wars and killings. But it can't be denied that in male-dominated society, women were the scapegoats to shoulder all the ruins, failures and destroy.

\section{Conclusions}

Women are not dangerous; they are not evils. But quite coincidently, women bore correlation with falling worldwide. People believed that it was Helen who caused Trojan War; it was Bao Si who led Zhou Youwang to cry wolf...... But wise men should be clear of the fact that women in fact, were not that powerful as depicted in novels and historic books. They were a group of weak ones who were deprived of their rights for so long a time; they were badly oppressed by their male counterpart, thus their voices couldn't be heard. They were beauties created by God to decorate the world, to make the world warm and colorful. But they were wrongly used by men-master of the world. No wonder so many stories of falling and ruin were related to them. No wonder they were often cursed by those who lost their belongings. For in the eyes of men, women were this kind of group who can be easily pushed to in front to danger and ruin. They shed their duties to women, and they treated women as their scapegoat.

Even figures like Milton, Shakespeare, who had shaped people's outlook couldn't get rid of the rigid thinking of "dangerous beauty", how can people expect the ordinary men to be responsible enough to shoulder their own responsibility, not leaving women to be blamed? It's high time men got to know the fact that women are not "dangerous beauty". They are their partners and friends. 
Together they can make the world more beautiful and warm.

\section{Acknowledgements}

This paper is part of the academic research on the project "The Archetype of Dangerous Beauty in Literature”, subjected to Science and Technology College of Hubei University. Project Number: KY201406.

\section{References}

[1], [2,3,4,5] Milton. John, Paradise Lost, Penguin Books, London, 1946.

[6] Milton. John, Samson Agonistes, Kessinger Publishing, Montana, 2010.

[7] Xun Lu, Lu Xun Collections, Volume 6, People’s Literature Publishing House, Beijing, 2005. (In Chinese).

[8] Shakespeare. William, William Shakespeare Four Tragedies, Penguin Books, London, 1994. 